\title{
POLA BAKTERI AEROB YANG BERPOTENSI MENYEBABKAN INFEKSI NOSOKOMIAL PADA KAMAR BERSALIN RSAD ROBERT WOLTER MONGISIDI MANADO
}

\author{
${ }^{1}$ Lisa E. Ritto \\ ${ }^{2}$ Standy Soeliongan \\ ${ }^{2}$ Fredine E.S Rares
}

\author{
${ }^{1}$ Kandidat Skripsi Fakultas Kedokteran Universitas Sam Ratulangi Manado \\ ${ }^{2}$ Bagian Mikrobiologi Fakultas Kedokteran Universitas Sam Ratulangi Manado \\ Email: lisaritto@gmail.com
}

\begin{abstract}
The situation in countries with limited resources, are radically different in almost every aspect, making pregnant women in developing countries prone to a higher risk of getting nosocomial infections after childbirth than their counterparts in developed countries. One of the most common cause of nosocomial infection is bacterial. The aim of this study was to determine the pattern of aerobic bacteria that could potentially cause nosocomial infection in delivery room RSAD Robert Wolter Monginsidi Manado and followed by isolation and identification of bacteria. This research uses descriptive method with prospective approach. Samples were taken by acquiring swabs from the walls, floor, room furniture, medical equipment, and air as much as 25 samples. As a result, there are Lactobacillus sp. 7 samples (28\%), Enterobacter agglomerans 7 samples (28\%), Bacillus subtilis 6 samples (24\%), Staphylococcus epidermidis 3 samples (12\%), Serratia liquefaciens 1 samples (4\%) and Enterobacter cloacae 1 samples (4\%). This study found the most bacteria are Lactobacillus sp. and Enterobacter agglomerans.
\end{abstract}

Keywords: aerobic bacteria, nosocomial infection, delivery room.

\begin{abstract}
Abstrak: Situasi di negara-negara dengan sumber-sumber yang terbatas, secara radikal berbeda hampir dalam setiap aspek membuat perempuan hamil di negara-negara sedang berkembang dihadapkan kepada resiko lebih tinggi untuk mendapatkan infeksi nosokomial sesudah persalinan daripada mitranya di negara-negara maju. Salah satu penyebab tersering infeksi nosokomial adalah bakteri. Tujuan dari penelitian ini adalah untuk mengetahui pola bakteri aerob yang berpotensi menyebabkan infeksi nosokomial pada kamar bersalin RSAD Robert Wolter Mongisidi Manado yang kemudian dilakukan isolasi dan identifikasi bakteri. Penelitian ini menggunakan metode penelitian deskriptif dengan pendekatan prospektif. Sampel diambil secara usapan dari dinding, lantai, perabotan ruangan, peralatan medis, dan udara sebanyak 25 sampel. Hasil penelitian ditemukan Lactobacillus sp. 7 sampel (28\%), Enterobacter agglomerans 7 sampel (28\%), Bacillus subtilis 6 sampel (24\%), Staphylococcus epidermidis 3 sampel (12\%), Serratia liquefaciens 1 sampel (4\%) dan Enterobacter cloacae 1 sampel (4\%). Kesimpulan dari penelitian ini bakteri terbanyak yang ditemukan adalah Lactobacillus sp. dan Enterobacter agglomerans.
\end{abstract}

Kata kunci: bakteri aerob, infeksi nosokomial, kamar bersalin

Rumah Sakit adalah institusi pelayanan kesehatan yang menyelenggarakan pelayanan kesehatan perorangan secara paripurna yang menyediakan pelayanan rawat inap, rawat jalan, dan gawat darurat. Pelayanan Kesehatan Paripurna adalah pelayanan kesehatan yang meliputi promotif, preventif, kuratif, dan 
rehabilitatif. ${ }^{1}$ Salah satu tujuan rumah sakit adalah memberikan perlindungan terhadap keselamatan pasien, masyarakat, lingkungan rumah sakit dan sumber daya manusia di rumah sakit. ${ }^{2}$ Namun tak jarang rumah sakit juga menjadi sumber infeksi yang dapat menyebabkan penyakit. Saat ini infeksi yang berkaitan dengan pelayanan kesehatan merupakan penyebab utama kematian di beberapa bagian dunia. ${ }^{3}$

Infeksi nosokomial (Hospital Acquired Infection/Nosocomial Infection) adalah infeksi yang didapat dari rumah sakit atau ketika penderita itu dirawat di rumah sakit. ${ }^{4}$ Infeksi nosokomial dapat ditransmisikan melalui petugas dan lingkungan. Transmisi melalui petugas bisa berasal dari kontaminasi tangan petugas; kontaminasi benda oleh darah, ekskreta, cairan tubuh lainnya; udara: dengan bersin dan batuk. Transmisi melalui lingkungan bisa berasal dari tikus, gigitan nyamuk, kontak dengan ekskreta, sirkulasi udara di RS, makanan dan obat-obatan di RS, air untuk minum dan kebersihan diri di RS. ${ }^{5}$ Infeksi lingkungan disebabkan oleh bakteri dari benda atau bahan yang tidak bersenyawa yang berada di lingkungan rumah sakit. Jenis mikroorganisme yang sering berpotensi terjadinya infeksi nosokomial yaitu: Proteus sp, Escherichia coli, Staphylococcus aureus, Candida albicans, dan Pseudomonas aeruginosa. ${ }^{6}$

Ratusan juta pasien di seluruh dunia terkena infeksi nosokomial setiap tahunnya, yang mengarah pada kematian yang signifikan dan kerugian keuangan untuk perawatan kesehatan. Beban endemik infeksi terkait infeksi nosokomial juga secara signifikan lebih tinggi pada negara berpenghasilan rendah dan menengah dari pada di negara-negara berpenghasilan tinggi. ${ }^{7}$ Di Amerika Serikat, Centers for Disease Control and Prevention (CDC) memperkirakan 1.7 juta infeksi nosokomial berkontribusi terhadap 99.000 kematian per tahun dan termasuk ke dalam 10 besar penyebab dari kematian. ${ }^{8}$ Di Eropa, setiap tahun diperkirakan lebih dari 4 juta pasien mengalami infeksi nosokomial. ${ }^{9}$ Menurut penelitian yang dilakukan Departemen
Kesehatan tahun 2004, prevalensi infeksi nosokomial di Indonesia banyak terjadi di rumah sakit pemerintah yaitu sebesar 35,8$55,1 \%$ dari jumlah pasien 991-1.527 orang dengan jumlah pasien berisiko sebesar 130.047-160.417 orang. $^{10}$

Kamar Bersalin adalah ruang yang berfungsi sebagai tempat pasien melahirkan bayinya termasuk kegiatan-kegiatan untuk tindakan saat persalinan. ${ }^{11}$ WHO memperkirakan kira-kira 210 juta wanita hamil setiap tahun dan 529.000 diantaranya meninggal karena komplikasi. Penyebab tersering kematian ibu terjadi pada periode post-partum, sepsis, dan pendarahan. Kebanyakan infeksi pasca persalinan disebabkan oleh flora endogen mikroorgaanisme yang biasanya ada dalam saluran genital. Sekurang-kurangnyakurangnya 20, termasuk Escherichia coli, Staphylococcus aureus, Proteus mirabilis dan Klebsiela pneumonia, adalah patogenik.

Sekitar 99\% kematian ibu terjadi pada negara berkembang. Bagaimanapun situasi di negara-negara dengan sumber-sumber yang terbatas, secara radikal berbeda hampir dalam setiap aspek. Sebagai akibatnya, perempuan hamil di negaranegara sedang berkembang dihadapkan kepada resiko lebih tinggi untuk mendapatkan infeksi nosokomial sesudah persalinan daripada mitranya di negaranegara maju. ${ }^{8,12}$

Berdasarkan uraian di atas, maka saya sebagai peneliti tertarik untuk melakukan penelitian tentang pemeriksaan bakteri penyebab infeksi nosokomial pada kamar bersalin RSAD Robert Wolter Mongisidi Manado.

\section{METODE PENELITIAN}

Penelitian ini bersifat deskriptif dengan pendekatan prospektif. Penelitian ini dilaksanakan pada bulan September Desember 2015. Lokasi pengambilan sampel dilakukan di kamar bersalin RSAD Robert Wolter Mongisidi Manado. Isolasi dan identifikasi bakteri dilakukan di Laboratorium Mikrobiologi Fakultas 
Kedokteran Universitas Sam Ratulangi Manado.

\section{HASIL PENELITIAN}

Jumlah sampel yang diambil berjumlah 25 sampel yang akan diuraikan pada tabel berikut.

Tabel 1. Uraian Pengambilan Sampel

\begin{tabular}{llc}
\hline Kategori & Sampel & $\begin{array}{c}\text { Jumlah } \\
\text { Sampel }\end{array}$ \\
\hline Ruang & Dinding & 4 \\
Perawatan & Lantai & 5 \\
Perabotan & Tempat Tidur & 4 \\
Ruangan & & \\
Peralatan Medis & Timbangan & 1 \\
& Bayi & 1 \\
& Box Bayi & 1 \\
& Alat USG & 1 \\
Udara & Kanul Oksigen & 4 \\
& Pagi & 4 \\
Total & Sore & $\mathbf{2 5}$ \\
\hline
\end{tabular}

Tabel 1 menyajikan uraian pengambilan sampel pada kamar bersalin. Pada ruang perawatan terdapat 9 sampel yang diambil pada 5 bagian lantai dan 4 bagian dinding. Selanjutnya diambil sampel pada perabotan ruangan, yaitu tempat tidur berjumlah 4 sampel. Pada perabotan medis diambil 4 sampel masing-masing 1 sampel pada timbangan bayi, box bayi, alat USG, dan kanul oksigen. Pada udara diambil 8 sampel, masing-masing 4 sampel pada udara pagi dan 4 sampel pada udara sore.
Dari 25 sampel yang diteliti, bakteri yang tumbuh pada Agar Nutrien berjumlah 25 sampel (100\%). Sedangkan bakteri yang tumbuh pada Agar Mac Conkey berjumlah 9 sampel (36\%).

Tabel 2. Distribusi Pertumbuhan Bakteri

\begin{tabular}{lcccc}
\hline Perbenihan & \multicolumn{2}{c}{ Media Isolasi } & \multicolumn{2}{c}{$(\mathbf{\%})$} \\
\cline { 2 - 5 } & $\begin{array}{c}\text { Agar } \\
\text { Nutrien }\end{array}$ & $\begin{array}{c}\text { Agar } \\
\text { Mac } \\
\text { Conkey }\end{array}$ & NA & MC \\
\hline $\begin{array}{l}\text { Ada } \\
\begin{array}{l}\text { Pertumbuhan } \\
\text { Tidak Ada } \\
\text { Pertumbuhan } \\
\text { Total }\end{array}\end{array}$ & 25 & 9 & 100 & 36 \\
\hline
\end{tabular}

Tabel 3. Hasil Pewarnaan Gram

\begin{tabular}{lcc}
\hline Pewarnaan & $\begin{array}{l}\text { Jumlah } \\
\text { Sampel }\end{array}$ & $\mathbf{( \% )}$ \\
\hline Bakteri Gram (+) & 16 & 64 \\
Bakteri Gram (-) & 5 & 20 \\
$\begin{array}{l}\text { Bakteri Gram (+) } \\
\text { dan Gram (-) }\end{array}$ & 4 & 16 \\
Total & 25 & 100 \\
\hline
\end{tabular}

Tabel 3 menggambarkan pada pewarnaan gram didapatkan bakteri yang paling banyak ditemukan adalah bakteri Gram positif berjumlah 16 sampel (64\%). Selanjutnya bakteri Gram negatif berjumlah 5 sampel (20\%) serta bakteri Gram positif dan negatif berjumlah 4 sampel (16 \%).

Tabel 4. Hasil Identifikasi Bakteri Secara Keseluruhan

\begin{tabular}{lccl}
\hline \multicolumn{1}{c}{ Bakteri } & Jumlah & $\mathbf{( \% )}$ & \multicolumn{1}{c}{ Sampel } \\
\hline Lactobacillus sp. & 7 & 28 & $\begin{array}{l}\text { Dinding, box bayi, tempat tidur, udara pagi, } \\
\text { udara siang }\end{array}$ \\
Enterobacter agglomerans & 7 & 28 & Lantai, tempat tidur, alat USG, udara sore \\
Bacillus Subtilis & 6 & 24 & Dinding, udara pagi, timbangan bayi \\
Staphylococcus epidermidis & 3 & 12 & Tempat tidur, kanul oksigen, udara siang \\
Enterobacter cloacae & 1 & 4 & Lantai \\
Serratia liquefaciens & 1 & 4 & Lantai \\
Total & 25 & 100 & \\
\hline
\end{tabular}


Tabel 4 menyajikan total bakteri yang ditemukan adalah sebanyak 25 bakteri. Pada hasil identifikasi bakeri ditemukan 6 spesies bakteri. Lactobacillus sp. dan Enterobacter agglomerans adalah bakteri yang paling banyak ditemukan, yaitu masing-masing sebanyak 7 sampel (28\%), disusul oleh Bacillus subtilis 6 sampel (24\%), Staphylococcus epidermidis 3 sampel (12\%), Enterobacter cloacaeae dan Serratia liquefaciens masing-masing 1 sampel (4\%).

Tabel 5 menunjukkan hasil identifikasi bakteri kategori ruang perawatan. Pada ruang perawatan diambil 9 sampel yang terbagi menjadi 5 sampel pada lantai dan 4 sampel pada dinding. Pada dinding terdapat bakteri Bacillus subtilis sebanyak 3 sampel (33.3\%) dan Lactobacillus sp. 1 sampel (11.1\%). Pada lantai ditemukan Enterobacter agglomerans 3 sampel (33.3\%). Serratia liquefaciens 1 sampel (11.1\%) dan Enterobacter cloacaeae 1 sampel (11.1\%).

Tabel 6 menjelaskan hasil identifikasi bakteri kategori perabotan ruangan. Dari 4 sampel yang diambil pada tempat tidur, bakteri yang ditemukan, yaitu Enterobacter agglomerans 2 sampel (50\%), Lactobacillus sp. 1 sampel (25\%), Staphylococcus epidermidis 1 sampel (25\%).

Tabel 5. Hasil Identifikasi Bakteri Kategori Ruang Perawatan

\begin{tabular}{lcc}
\hline \multicolumn{1}{c}{ Bakteri } & Jumlah & (\%) \\
\hline $\begin{array}{l}\text { Dinding } \\
\text { Bacillus Subtilis } \\
\text { Lactobacillus sp. }\end{array}$ & 3 & 33.3 \\
$\begin{array}{l}\text { Lantai } \\
\text { Enterobacter }\end{array}$ & 1 & 11.1 \\
$\begin{array}{l}\text { agglomerans } \\
\quad \begin{array}{l}\text { Serratia } \\
\text { liquefaciens } \\
\quad \text { Enterobacter } \\
\text { cloacae } \\
\text { Total }\end{array}\end{array}$ & 1 & 33.3 \\
\hline
\end{tabular}

Tabel 6. Hasil Identifikasi Bakteri Kategori Perabotan Ruangan

\begin{tabular}{|c|c|c|c|}
\hline Bakteri & Jumlah & $(\%)$ & Sampel \\
\hline $\begin{array}{l}\text { Enterobacter } \\
\text { agglomerans }\end{array}$ & 2 & 50 & $\begin{array}{l}\text { Tempat } \\
\text { tidur }\end{array}$ \\
\hline $\begin{array}{l}\text { Lactobacillus } \\
\text { sp. }\end{array}$ & 1 & 25 & $\begin{array}{l}\text { Tempat } \\
\text { tidur }\end{array}$ \\
\hline $\begin{array}{l}\text { Staphylococcu } \\
\text { s epidermidis }\end{array}$ & 1 & 25 & $\begin{array}{l}\text { Tempat } \\
\text { tidur }\end{array}$ \\
\hline Total & 4 & 100 & \\
\hline
\end{tabular}

Untuk kategori peralatan medis diambil 4 sampel dan ditemukan bakteri Bacillus subtilis 1 sampel (25\%) pada timbangan bayi, Lactobacillus sp. 1 sampel (25\%) pada box bayi, Staphylococcus epidermidis 1 sampel (25\%) pada kanul oksigen, serta Enterobacter agglomerans 1 sampel (25\%) pada USG.

Tabel 7. Hasil Identifikasi Bakteri Kategori Peralatan Medis

\begin{tabular}{|c|c|c|c|}
\hline Bakteri & Jumlah & (\%) & Sampel \\
\hline $\begin{array}{l}\text { Bacillus } \\
\text { subtilis }\end{array}$ & 1 & 25 & $\begin{array}{l}\text { Timbang } \\
\text { an Bayi }\end{array}$ \\
\hline $\begin{array}{l}\text { Lactobacillus } \\
\text { sp. }\end{array}$ & 1 & 25 & $\begin{array}{l}\text { Box } \\
\text { Bayi }\end{array}$ \\
\hline $\begin{array}{l}\text { Staphylococcu } \\
\text { s epidermidis }\end{array}$ & 1 & 25 & $\begin{array}{l}\text { Kanul } \\
\text { Oksigen }\end{array}$ \\
\hline $\begin{array}{l}\text { Enterobacter } \\
\text { agglomerans }\end{array}$ & 1 & 25 & $\begin{array}{l}\text { Alat } \\
\text { USG }\end{array}$ \\
\hline Total & 4 & 100 & \\
\hline
\end{tabular}

Tabel 8. Hasil Identifikasi Bakteri Kategori Udara

\begin{tabular}{lcc}
\hline \multicolumn{1}{c}{ Bakteri } & Jumlah & $\mathbf{( \% )}$ \\
\hline Udara Pagi & & \\
$\quad$ Lactobacillus sp. & 2 & 25 \\
$\quad \begin{array}{l}\text { Bacillus subtilis } \\
\text { Udara Sore }\end{array}$ & 2 & 25 \\
$\quad \begin{array}{l}\text { Lactobacillus sp. } \\
\quad \begin{array}{l}\text { Staphylococcus } \\
\text { epidermidis }\end{array}\end{array}$ & 2 & 25 \\
$\quad \begin{array}{l}\text { Enterobacter } \\
\text { agglomerans }\end{array}$ & 1 & 12.5 \\
Total & & 12.5 \\
\hline
\end{tabular}


Untuk kategori udara diambil 8 sampel masing-masing 4 sampel pada udara pagi dan 4 sampel pada udara sore. Udara pagi diambil pada jam 8 sampai 9 pagi sedangkan udara sore diambil pada jam 3 sampai 4 sore. Pada udara pagi ditemukan ditemukan Lactobacillus sp. dan Bacillus subtilis masing-masing 2 sampel (25\%). Sedangkan pada udara sore ditemukan Lactobacillus sp. 2 sampel (25\%) serta Staphylococcus epidermidis dan Enterobacter agglomerans masing-masing 1 sampel (12.5\%).

\section{BAHASAN}

Pada kategori ruang perawatan ditemukan bakteri Gram positif pada dinding, yaitu Bacillus subtilis dan Lactobacillus sp. Dari 9 sampel yang diambil ditemukan Bacillus subtilis sebanyak 3 sampel (33,3\%). Berbeda dengan penelitian yang dilakukan oleh Yassin dan Ahmad pada rumah sakit pendidikan Azadi di kota Duhok, Irak, dari 45 sampel yang diambil pada lingkungan rumah sakit (lantai, dalam ruangan, jendela, dan dinding) ditemukan 10 sampel yang positif terdapat Bacillus subtilis. ${ }^{13}$ Pada sampel di lantai semuanya terdapat batang Gram negatif enterik kelompok Enterobacteriaceae, yaitu E. agglomerans, $S$. liquefaciens dan E. cloacaeae. Kelompok bakteri Enterobacteriaceae tersebar luas dan biasa ditemukan pada tanah, air, tanaman, manusia, dan hewan. ${ }^{14}$ Kemungkinan ditemukannya bakteribakteri ini pada lantai adalah lewat air pel yang tidak mengandung cairan antiseptik pembersih lantai atau lewat alas kaki yang terkontaminasi dengan dunia luar.

Pada perabotan ruangan yang diambil sampel pada tempat tidur terdapat $E$. agglomerans, Lactobacillus sp., dan Staphylococcus epidermidis. Penelitian ini berbeda dengan bakteri yang ditemukan pada tempat tidur di ICU BLU RSUP Prof. DR. R. D. Kandou Manado dimana bakteri yang ditemukan adalah Serratia rubidaea, Kokus Gram negatif, dan Staphylococcus $s p .{ }^{15}$ Perbedaan pertumbuhan bakteri pada kedua tempat ini merupakan hal yang wajar karena kamar bersalin dan ICU merupakan dua tempat yang berbeda dari segi fungsi dan tipe pasien yang dirawat di dalammnya.

Pada peralatan medis ditemukan masing-masing 1 sampel Bacillus subtilis pada timbangan bayi dan Lactobacillus sp. pada box bayi. Kedua bakteri ini juga ditemukan pada peralatan medis di ruangan Neonatal Intensive Care Unit (NICU) BLU RSUP Prof. DR. R. D Kandou Manado. Lactobacillus sp. ditemukan dalam jumlah yang sama dan merupakan bakteri non patogen utama pada pemberian susu. Sedangkan Bacillus sutbtilis ditemukan sebanyak 8 sampel. ${ }^{16}$ Pada kanul oksigen yang berbahan polimer ditemukan Staphylococcus epidermidis. Studi dalam beberapa tahun terakhir telah jelas menunjukkan bahwa kemampuan dari bakteri untuk menebal, membentuk biofilm berlapis pada permukaan yang lembam seperti polimer atau logam merupakan ciri khas dari banyak hasil isolasi nosokomial bakteri ini. ${ }^{17}$ Dengan demikian hasil studi ini menyarankan bahwa berbagai peralatan medis yang seperti cardiotocograph, infus, alat resusitasi untuk dewasa, oxygen set dan flow meter, suction pump, stetoskop, alat USG serta peralatan medis lainnya yang berbahan polimer dan logam perlu diwaspadai akan pertumbuhan patogen dari bakteri ini. Pada alat USG ditemukan bakteri Gram negatif, yaitu E. agglomerans. Hasil penelitian dari Nunez, Moreno, Green, dan Villar menunjukkan bahwa bakteri yang sama juga ditemukan pada stetoskop yang dipakai oleh dokter dan perawat pada unit gawat darurat. ${ }^{18}$

Konsentrasi maksimum mikroorganisme per meter persegi udara untuk kamar bersalin adalah $200 \mathrm{CFU} / \mathrm{m} 3 .^{19}$ Pada udara sore ditemukan lebih banyak bakteri dari pada udara pagi. Pada udara pagi ditemukan 2 spesies bakteri yaitu Lactobacillus sp. dan Bacillus subtilis. Sedangkan pada udara sore ditemukan 3 spesies yaitu Lactobacillus sp., Staphylococcus epidermidis, dan Enterobacter agglomerans. Penelitian ini berkorelasi dengan penelitian di Rivers 
State Nigeria yang menyatakan bahwa populasi bakteri lebih tinggi pada udara sore hari. ${ }^{20}$ Ada kemungkinan hal ini disebabkan oleh frekuensi pasien dan sinar matahari. Pada pagi hari jumlah pasien masih sedikit dan bantuan dari sinar matahari mampu membunuh beberapa kuman tertentu. Sedangkan pada sore hari frekuensi pasien mulai meningkat dan tidak mendapat sinar matahari sehingga populasi bakteri bertambah. Namun hal ini masih perlu dibuktikan dengan penelitian lebih lanjut.

Penelitian yang dilakukan di rumah sakit Besat, Sanandaj, Iran bakteri penyebab infeksi nosokomial yang paling banyak ditemukan adalah E. coli $(44.51 \%)$, S. aureus $(4.31 \%), \quad S$. epidermidis (14.28\%), Streptococcus spp. (8.63\%), Klebsiella spp. (8.30\%), Pseudomonas spp. (5.98\%), Serratia spp. (2.65\%), Acinetobacter spp. (5.98\%), Enterobacter spp. (3.98\%), and Citrobacter spp. $(1.32 \%) .{ }^{21}$ Sedangkan pada penelitian ini bakteri yang paling banyak ditemukan di kamar bersalin adalah Lactobacillus sp. 7 sampel (28\%), Enterobacter agglomerans 7 sampel (28\%), Bacillus subtilis 6 sampel (24\%), Staphylococcus epidermidis 3 sampel (12\%), Serratia liquefaciens 1 sampel (4\%) dan Enterobacter cloacae 1 sampel (4\%).

Masih kurangnya sterilisasi ruangan, udara, dan peralatan medis merupakan faktor penyebab ditemukannya bakteri yang berpotensi menyebabkan infeksi nosokomial pada kamar bersalin sehingga disarankan supaya pihak rumah sakit lebih memperhatikan lagi secara rutin sterilisasi dari ruangan, udara, dan peralatan medis yang digunakan.

Penelitian mengenai pola bakteri aerob yang berpotensi menyebabkan infeksi nosokomial pada kamar bersalin belum pernah dilakukan sebelumnya sehingga hasil penelitian ini tidak bisa dibandingkan dengan penelitan sebelumnya.

\section{SIMPULAN}

Berdasarkan penelitan mengenai pola bakteri aerob yang berpotensi menyebabkan infeksi nosokomial pada kamar bersalin RSAD Robert Wolter Mongisidi Manado periode September Desember 2015 maka dapat disimpulkan sebagai berikut :

1. Berdasarkan hasil identifikasi pertumbuhan bakteri ditemukan 6 spesies bakteri, yaitu Lactobacillus sp. 7 sampel (28\%), Enterobacter agglomerans 7 sampel (28\%), Bacillus subtilis 6 sampel (24\%), Staphylococcus epidermidis 3 sampel (12\%), Serratia liquefaciens 1 sampel (4\%) dan Enterobacter cloacae 1 sampel (4\%).

2. Jumlah pertumbuhan bakteri Gram positif lebih banyak dari Gram negatif namun sama banyak dari segi spesies.

3. Lactobacillus sp. dan Enterobacter agglomerans merupakan bakteri terbanyak yang ditemukan.

\section{SARAN}

1. Penelitian ini dapat dijadikan bahan penelitian berikutnya mengenai pola bakteri aerob yang berpotensi menyebabkan infeksi nosokomial di kamar bersalin.

2. Pihak rumah sakit perlu meningkatkan sanitasi dan kebersihan lingkungan rumah sakit, terutama membersihkan secara rutin lantai dan tempat tidur pasien.

3. Semua pertalatan medis yang digunakan harus disterilkan terlebih dahulu.

4. Penelitian ini dapat dilanjutkan dengan penelitian tentang uji kepekaan antibiotika pada bakteri penyebab infeksi nosokomial pada kamar bersalin.

\section{DAFTAR PUSTAKA}

1. Undang-undang Republik Indonesia. Rumah Sakit. 2009;1:1-3. [dikunjungi 2015 September 25]. Diunduh dari : http://www.bpkp.go.iduufiledownload2 26119.bpkp.

2. Undang-undang Republik Indonesia. Rumah Sakit. 2009;2:3b. [dikunjungi 2015 September 25]. Diunduh dari: http://www.bpkp.go.iduufiledownload2 
26119.bpkp.

3. Zuhrotul A, Satyabakti P. Surveilans Infeksi Daerah Operasi (IDO) Menurut Komponen Surveilans Di Rumah Sakit $\mathrm{X}$ Surabaya. Fakultas Kesehatan Masyarakat Universitas Airlangga. 2012

4. Nugraheni R, Suhartono, Winarni S.

Infeksi Nosokomial di RSUD Setjonegoro Kabupaten Wonosobo. Media Kesehatan Masyarakat Indonesia. 2012;11.

5. Zuhriyah L. Gambaran Bakteriologis Tangan Perawat. Jurnal Kedokteran Brawijaya. 2004;XX.

6. Baharutan A, Rares FES, Soeliongan S. Pola Bakteri Penyebab

Infeksi Nosokomial PadaRuang Perawatan Intensif Anak Di BLU RSUP Prof. DR. R. D. Kandou Manado. e-Biomedik (eBm). 2015;3.

7. Patient Safety A World Alliance For Safer Health Care. Health-Care Associated Infection Fact Sheet. WHO.

8. Unahalekhaka, A. Epidemiology of Health care-Associated Infections. In: Friedman C, Newsom W. IFIC Basic Concepts of Infection Control. 2nd ed. Malta: Bonavia Offset Printers; 2011.p. 27-29, 204

9. Clean Care is Safer Care Team. Report on the burden of endemic health careassociated infection worldwide. Geneva: World Health Organization Press; 2011.

10.Angga IL, Prenggono MD, Budiarti LY. Identifikasi Jenis Bakteri

Kontaminan Pada Tangan Perawat Di Bangsal Penyakit Dalam RSUD Ulin Banjarmasin Periode Juni-Agustus 2014. Berkala Kedokteran. 2015;11:1118.

11. Pedoman Teknis Sarana dan Prasarana Rumah Sakit Kelas C. Departemen Kesehatan RI Sekretariat Jenderal Pusat Sarana, Prasarana dan Peralatan Kesehatan; 2007.

12. Irianto K. Mikrobiologi Medis. Bandung: Alfabeta; 2013. p. 107-8,
136-42.

13. Yassin NA, Ahmad AM. Incidence and Resistotyping Profiles of Bacillus subtilis Isolated from Azadi Teaching Hospital in Duhok City, Iraq. Mater Sociomed. 2012;24:194-97.

14. Public Health of England. UK Standards for Microbiology Investigations: Identification of Enterobacteriaceae. 2015;4:9-10

15.Londok PV, Homenta H, Buntuan V.Pola Bakteri Aerob Yang Berpotensi Menyebabkan Infeksi Nosokomial di Ruang ICU BLU RSUP Prof. DR. R. D. Kandou Manado. eBM. 2015;3

16. Saleh M, Rares FES, Soeliongan $S$. Pola Bakteri Aerob Penyebab Infeksi Nosokomial Pada Ruangan Neonatal Intensive Care Unit (NICU) BLU RSUP Prof. DR. R. D. Kandou Manado. eBM. 2015;3

17.Ziebuhr I, Hennig S, Eckart M, Kranzler H, Batzilla C, Kozitskaya S. Nosocomial infections by Staphylococcus epidermidis: how a commensal bacterium turns into a pathogen. International Journal of Antimicrobial Agents. 2006;28:14-20.

18.Nunez S, Moreno A, Green K, Villar J. The stethoscope in the emergency department: a vector of infection?. Epidemiology and Infection. 2000;124:233-37.

19. Keputusan Menteri Kesehatan

Republik Indonesia. Persyaratan Kesehatan Lingkungan dan Rumah Sakit. Jakarta. 2004.

20.Agbagwa, Obakpororo E, Onyemaechi, Sandra A.

Microbiological quality of indoor air of a general hospital and a health center in Rivers State Nigeria.

21.Lavakhamseh H, Shakib $P$, Rouhi S, Mohammadi B, Ramazanzadeh R.

A Survey on the Prevalence and Antibiotic Sensitivity of Nosocomial Infections in the Besat Hospital, Sanandaj, Iran. Journal NI. 2014;1:1-8. 